Article

\title{
Characterization of Low-Symmetry Structures from Phase Equilibrium of Fe-Al System-Microstructures and Mechanical Properties
}

\author{
Piotr Matysik *, Stanisław Jóźwiak and Tomasz Czujko \\ Department of Advanced Materials and Technologies, Faculty of Advanced Technologies and \\ Chemistry, Military University of Technology, Gen. S. Kaliskiego 2 St., Warsaw 00-908, Poland; \\ E-Mails: sjozwiak@wat.edu.pl (S.J.); tczujko@wat.edu.pl (T.C.) \\ * Author to whom correspondence should be addressed; E-Mail: pmatysik@wat.edu.pl; \\ Tel.: +48-22-683-00-00; Fax: +48-22-683-94-45.
}

Academic Editor: Marco Salerno

Received: 20 December 2014 / Accepted: 15 February 2015 / Published: 4 March 2015

\begin{abstract}
Fe-Al intermetallic alloys with aluminum content over 60 at $\%$ are in the area of the phase equilibrium diagram that is considerably less investigated in comparison to the high-symmetry $\mathrm{Fe}_{3} \mathrm{Al}$ and $\mathrm{FeAl}$ phases. Ambiguous crystallographic information and incoherent data referring to the phase equilibrium diagrams placed in a high-aluminum range have caused confusions and misinformation. Nowadays unequivocal material properties description of $\mathrm{FeAl}_{2}, \mathrm{Fe}_{2} \mathrm{Al}_{5}$ and $\mathrm{FeAl}_{3}$ intermetallic alloys is still incomplete. In this paper, the influence of aluminum content and processing parameters on phase composition is presented. The occurrence of low-symmetry $\mathrm{FeAl}_{2}, \mathrm{Fe}_{2} \mathrm{Al}_{5}$ and $\mathrm{FeAl}_{3}$ structures determined by chemical composition and phase transformations was defined by scanning electron microscopy (SEM) and energy-dispersive X-ray spectroscopy (EDS) examinations. These results served to verify diffraction investigations (XRD) and to explain the mechanical properties of cast materials such as: hardness, Young's modulus and fracture toughness evaluated using the nano-indentation technique.
\end{abstract}

Keywords: Al-Fe alloy; microstructure; mechanical properties; SEM/EDS; XRD; nano-indentation 


\section{Introduction}

Iron aluminides are considered as structural and functional materials, increasingly used as intermetallic sinters [1-10], graded materials [11], or in the form of HVOF and gas detonation sprayed layers [12-14]. Unfortunately, it should be noted that the functional properties of these alloys, especially the mechanical properties, are determined only for the relatively plastic $\mathrm{FeAl}$ and $\mathrm{Fe}_{3} \mathrm{Al}$ phases and solid solution with aluminum content restricted to $50 \mathrm{at} \%$. In the case of Al-rich phases from the $\mathrm{Fe}-\mathrm{Al}$ system $\left(\mathrm{aP}_{18} \mathrm{FeAl}_{2}\right.$, oC14 $\mathrm{Fe}_{2} \mathrm{Al}_{5}$, and $\left.\mathrm{mC}_{102} \mathrm{FeAl}_{3}\right)$, the area of their occurrence has not been well-defined yet. Despite to the research undertaken in order to complement or present a detailed description of their mechanical properties depending on manufacturing parameters, e.g., temperature, pressure and chemical composition [15-22], the presented results are often ambiguous and contradictory [7,10,23-31]. Ambiguities within determining the fields of structural stability of the Al-rich phases in the description of the Fe-Al system drastically reduce the potential use of these structures in the techniques of aluminum coating, soldering and welding [32-34] as well as sintering elementary iron and aluminum powders [35-38].

Therefore, in this paper we attempt to clarify the aluminum content ranges responsible for changes in the crystal structure of the analyzed Al-rich phases. The measurements of selected mechanical properties were made for polycrystalline disordered intermetallic alloys based on phases-Triclinic $\mathrm{FeAl}_{2}$, orthorhombic $\mathrm{Fe}_{2} \mathrm{Al}_{5}$ and monoclinic $\mathrm{FeAl}_{3}$ in which low crystal symmetry prevents the disorder-Order transformation. The authors pointed out the need for further research in this area, particularly that leading to clarify the phase transformation processes.

\section{Results and Discussion}

\subsection{Structural Studies}

The microstructure of samples with various aluminum content after sintering and annealing at $1200{ }^{\circ} \mathrm{C} / 24 \mathrm{~h}$ is presented in Figure 1. The important differences in phase composition result from the stoichiometry of the structural components and phase transformations occurring during the sintering and homogenization processes. The samples with aluminum content in the range of $56.0-65.5$ at $\%$ are characterized by a dual phase $\mathrm{FeAl}-\mathrm{FeAl}_{2}$ structure determined by EDS examinations in micro areas. Moreover, the mixture of $\mathrm{FeAl}+\mathrm{FeAl}_{2}$ crystals is observed. It results from the eutectoid reaction of the $\varepsilon\left(\mathrm{Fe}_{5} \mathrm{Al}_{8}\right)$ phase decomposition at $1092{ }^{\circ} \mathrm{C}$. A single phase homogeneous sinter which is composed of $\mathrm{FeAl}_{2}$ perytectoid grains (Figure $1 \mathrm{~b}$ ) was observed for the sample with aluminum content amounting to 68 at\% (Figure 1).

The continuous precipitates within the intermetallic matrix visible in Figure 1a for the above chemical composition ( $68 \mathrm{at} \% \mathrm{Al}$ ) are identified as aluminum oxides. They are an integral structural element occurring during sintering process of mixtures containing strongly passivating aluminum powder. The increase of aluminum concentration from 68 at $\% \mathrm{Al}$ which is a typical content for the $\varepsilon+\mathrm{Fe}_{2} \mathrm{Al}_{5} \leftrightarrow \mathrm{FeAl}_{2}$ peritectoid reaction to 70 at $\%$ results in the creation of a dual-phase structure. This structure consists of the $\mathrm{FeAl}_{2}$ phase, formed as a result of the peritectoid reaction, and the $\mathrm{Fe}_{2} \mathrm{Al}_{5}$ phase crystallized from liquid. The next, in terms of the increasing aluminum content, phase-homogeneous sinter made of the $\mathrm{Fe}_{2} \mathrm{Al}_{5}$ phase identified during XRD analysis (Figure 1b), was obtained for 72 at $\% \mathrm{Al}$ 
(Figure 1a). The next, single-phase alloy of the Fe-Al system, produced using powder metallurgy, was obtained for $77.5 \mathrm{at} \% \mathrm{Al}$. This value of aluminum content in the structure of the single-phase homogenous alloy, identified as the $\mathrm{FeAl}_{3}$ phase, is slightly higher than the stoichiometry given by Kubaschewski (Figure 2) which equals to 75 at $\%$ Al. The noticed discrepancy requires additional confirmation but shows ambiguities not only in the interpretation of the content of the components constituting the phase data.

๑))
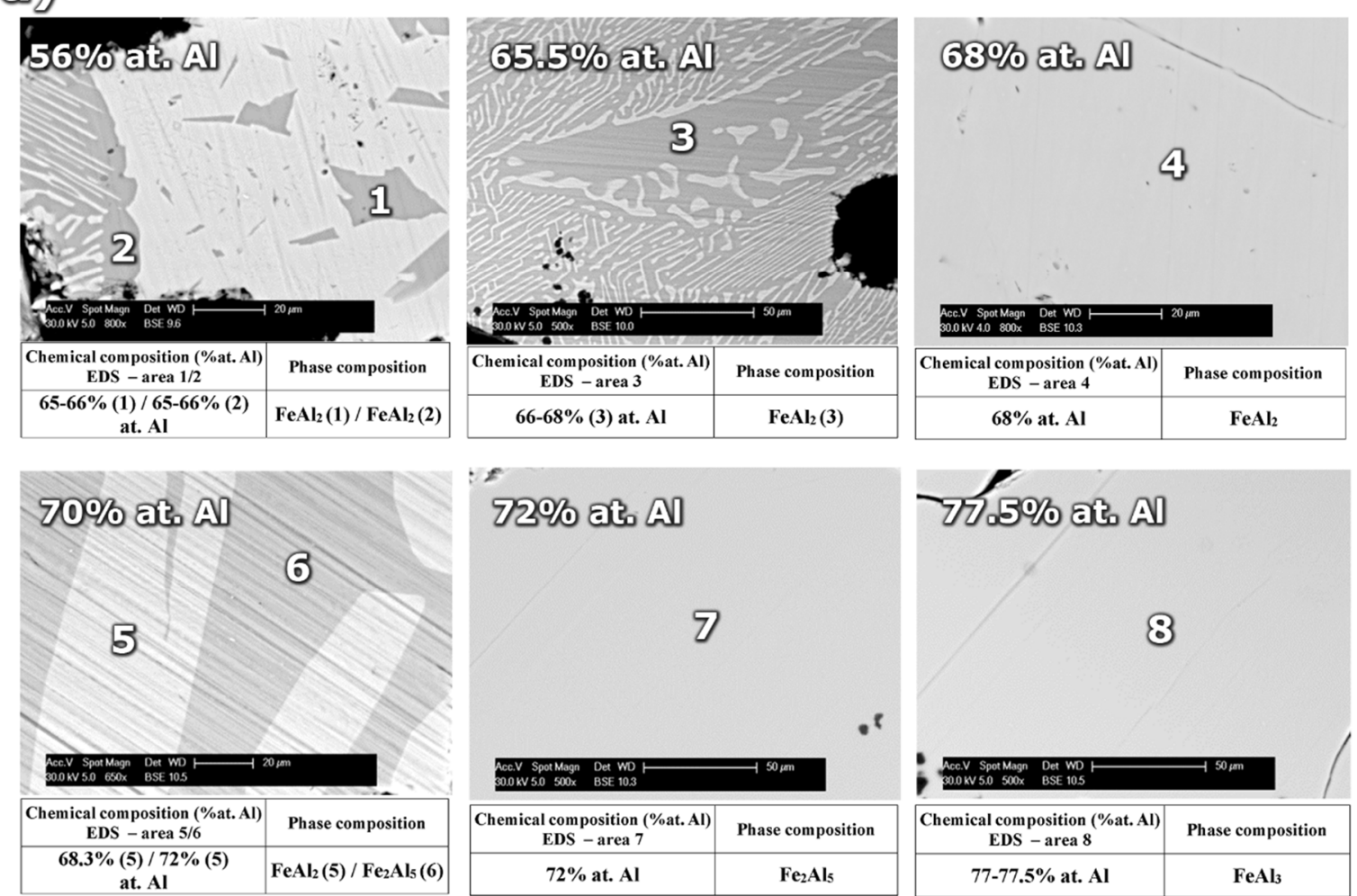

У

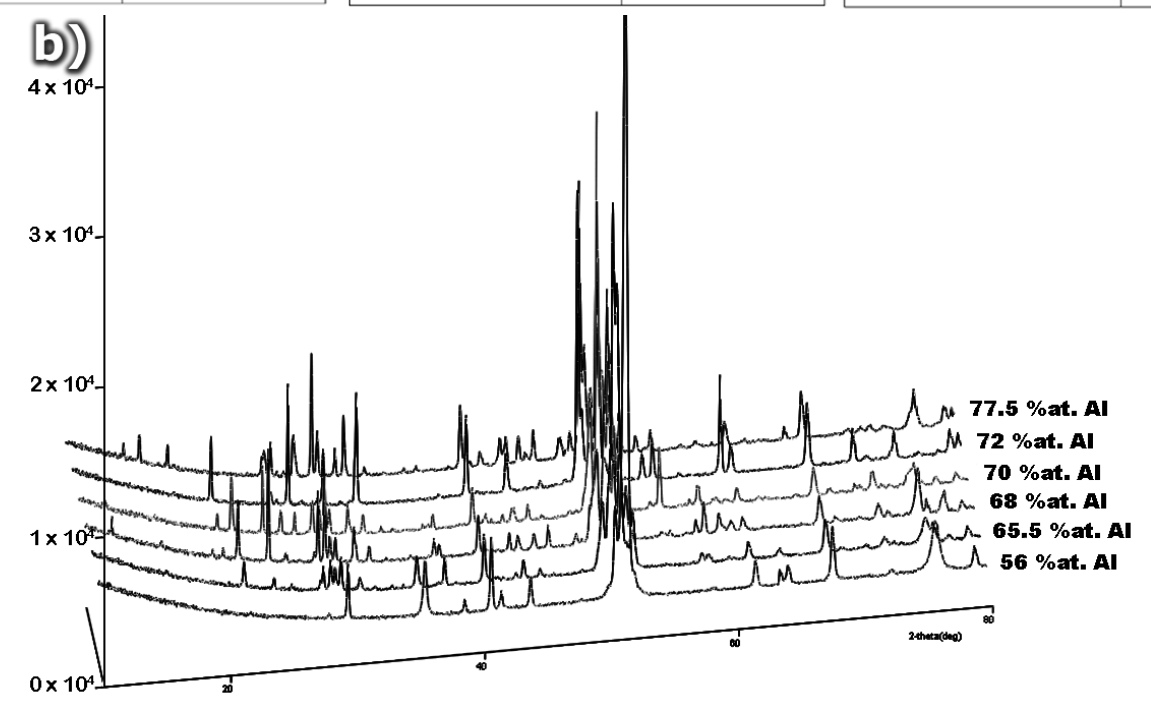

Figure 1. (a) The microstructure and (b) XRD phase analysis of homogenized sinters as a function of aluminum content. 


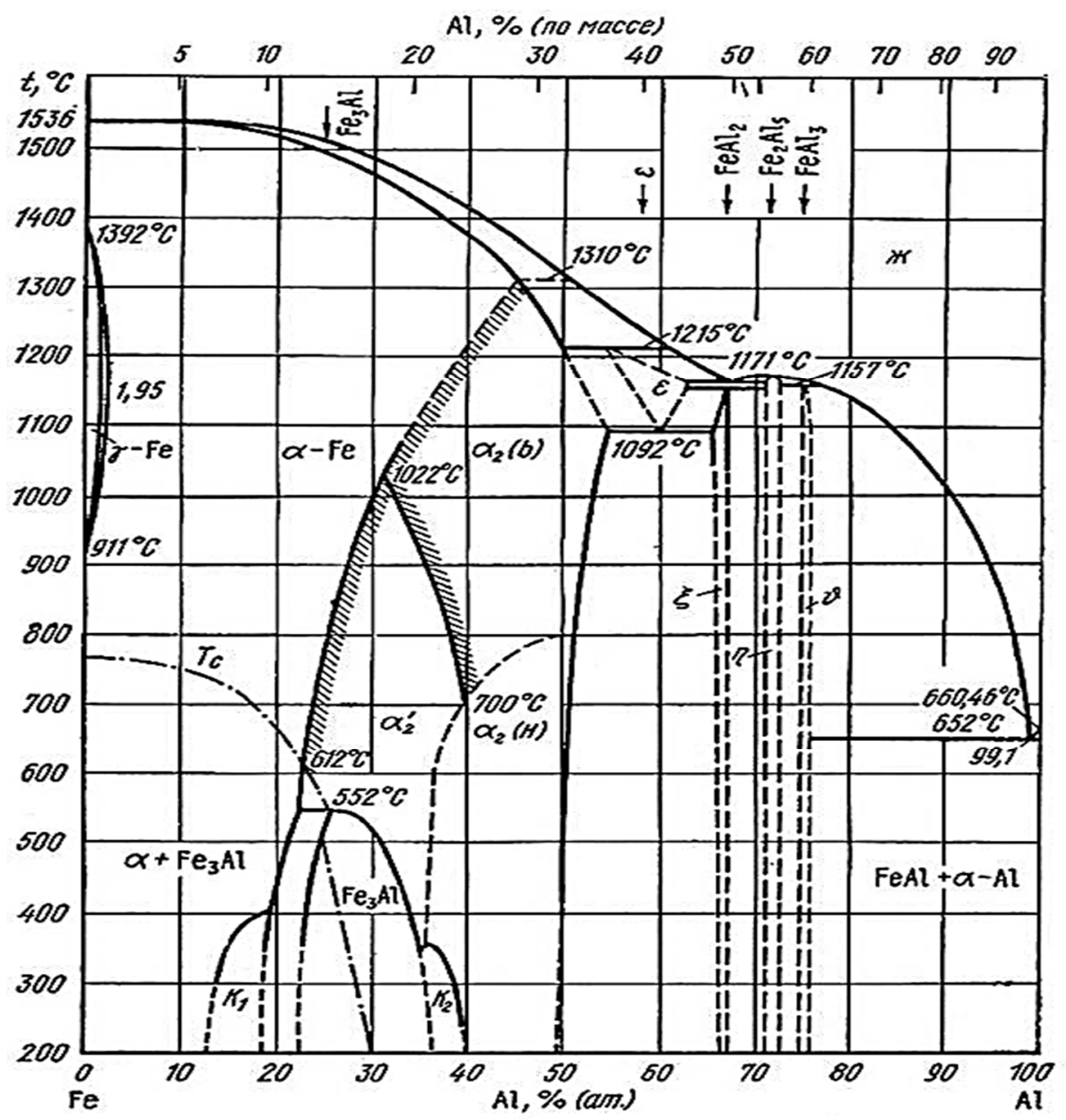

Figure 2. Fe-Al binary diagram proposed by Kubaschewski and approved during Discussion Meeting on the Development of Innovative Iron Aluminum Alloys, for analysis and phase transformation interpretation in iron-aluminum alloys. Ambiguous area of Al-rich phases occurrence were marked by dashed line [19].

Nonetheless, the results obtained during the study on the content of aluminum in sintered materials, which allows the formation of homogeneous Al-rich intermetallic $\mathrm{FeAl}_{2}, \mathrm{Fe}_{2} \mathrm{Al}_{5}$ and $\mathrm{FeAl}_{3}$ phases, enabled the forming of alloys with anticipated crystalline structure by melting and vacuum casting. What is more important, obtained by these methods alloys are devoid of oxide precipitates.

Similar effects during melting and casting of Fe-Al alloys were also observed by Hirose et al. [39] and Gąsior et al. [40]. The low symmetry of the arrangement of the elementary cells of these phases, as reflected in the impeded phenomena of diffusion of the atoms of components, causes differences in the structure and chemical composition. This effect takes place during crystallization [39], which is substantially depended on the method and rate of cooling or subsequent thermal treatment [40]. In addition, possible fluctuations in the chemical composition of the metal liquid in conjunction with the temperature of the peritectic $\varepsilon\left(\mathrm{Fe}_{5} \mathrm{Al}_{8}\right)$ transition $\left(1215^{\circ} \mathrm{C}\right)$ being higher than in the case of the eutectic $\varepsilon+\mathrm{Fe}_{2} \mathrm{Al}_{5}$ transformation at $1164{ }^{\circ} \mathrm{C}$ (Figure 3), lead to formation of the three-phase structure (Figure $4 \mathrm{c}$ ). It is despite the fact that aluminum content provides the $\mathrm{FeAl}_{2}$ formation. 


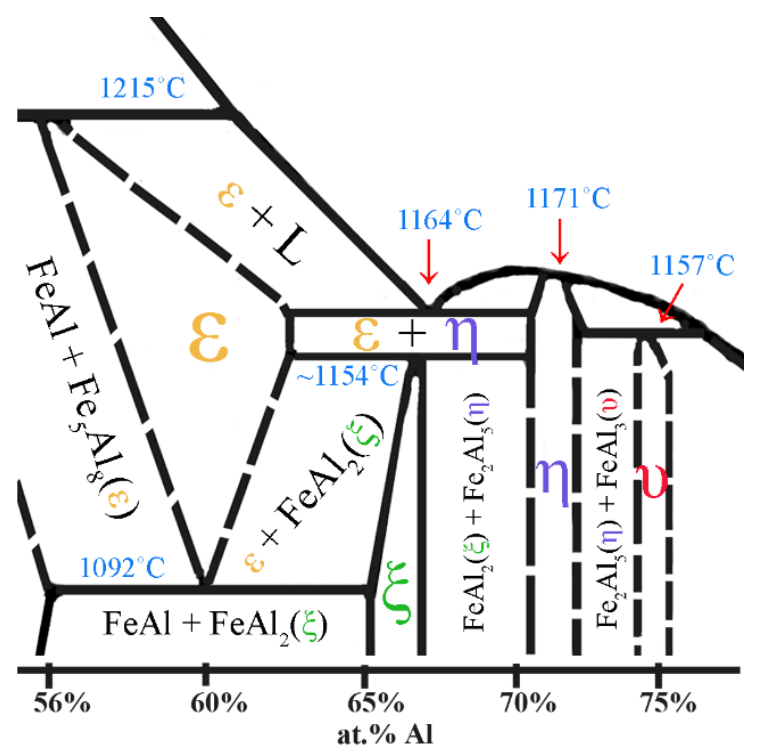

Figure 3. The part of Fe-Al phase binary diagram presenting the area of formation and transformations of Al-rich phases (made on the base of [15-20]).
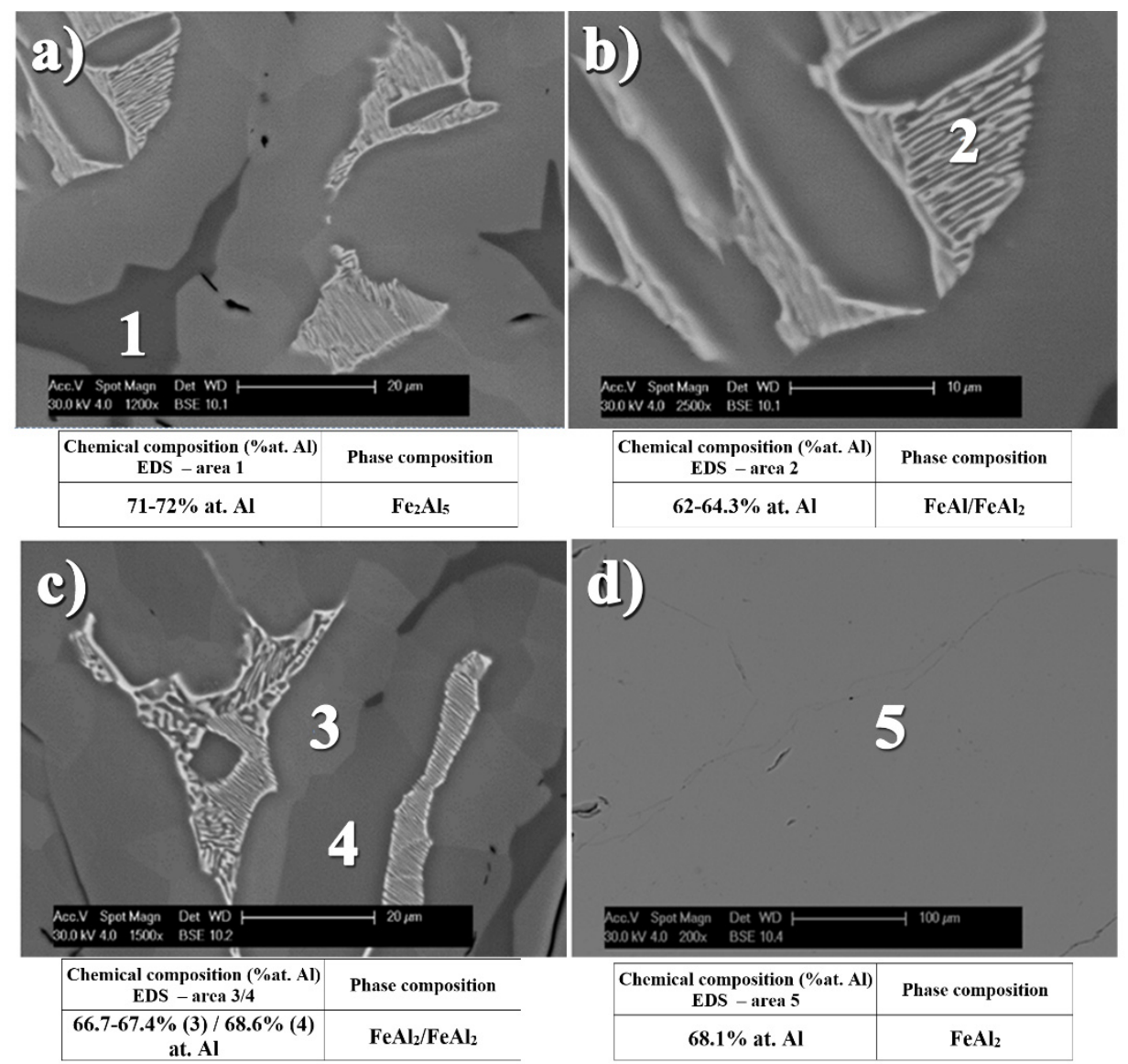

Figure 4. Inhomogeneous phase microstructure of material form $\mathrm{Fe}-\mathrm{Al}$ system after crystallization $(\mathbf{a}-\mathbf{c})$ and homogenization to $\mathrm{FeAl}_{2}$ phase, as the result of annealing at temperature $1050{ }^{\circ} \mathrm{C}$ for $100 \mathrm{~h}(\mathbf{d})$. 
The performed microanalysis of the chemical composition in the areas of the various phase components formed in the investigated samples allows describing the sequence of phase transformation occurring in these alloys. During the cooling of the crystallized eutectic mixture $\left(\varepsilon+\mathrm{Fe}_{2} \mathrm{Al}_{5}\right)$ with the peritectic $\varepsilon$, a successive phase transition takes place very quickly leading to the formation of the $\mathrm{FeAl}_{2}$ peritectoid at temperature about $1154{ }^{\circ} \mathrm{C}$. Afterward at the temperature of $1092{ }^{\circ} \mathrm{C}$ the $\varepsilon$ peritectic transforms into the eutectoid $\mathrm{FeAl}+\mathrm{FeAl}_{2}$ mixture as a result of the eutectoid reaction. The difficult diffusion of atoms formed in the low-symmetry structures is also a likely cause of that differences in the content of aluminum in the locally formed $\mathrm{FeAl}_{2}$ phase which contains 66.7-68.1 at $\%$ of aluminum. Whenever the eutectoid $\mathrm{FeAl}+\mathrm{FeAl}_{2}$ mixture resulting from the $\varepsilon$ $\left(\mathrm{Fe}_{5} \mathrm{Al}_{8}\right)$ phase is characterized by the aluminum content at the level of $62-64.3 \mathrm{at} \%$. Whereas the congruent $\mathrm{Fe}_{2} \mathrm{Al}_{5}$ phase, crystallizing at the temperature of $1171{ }^{\circ} \mathrm{C}$, comprises $71-72$ at $\%$ of this element. This multi-phase structure of the assumed total aluminum content of 68 at $\%$ after $100 \mathrm{~h}$ of annealing at $1050{ }^{\circ} \mathrm{C}$ is remodeled by diffusion into a single-phase material corresponding with its chemical composition to the $\mathrm{FeAl}_{2}$ Al-rich phase (Figure 4d).

The performed X-ray phase analysis confirmed the results of EDS analysis, allowing for the identification of the single-phase structure obtained by homogenizing the crystallized ingots assuming the chemical composition of the Al-rich alloys, respectively, $\mathrm{FeAl}_{2}-68$ at $\% \mathrm{Al}, \mathrm{Fe}_{2} \mathrm{Al}_{5}-72$ at $\% \mathrm{Al}$, and $\mathrm{FeAl}_{3}-77.5$ at\% $\mathrm{Al}$ (Figure 5).

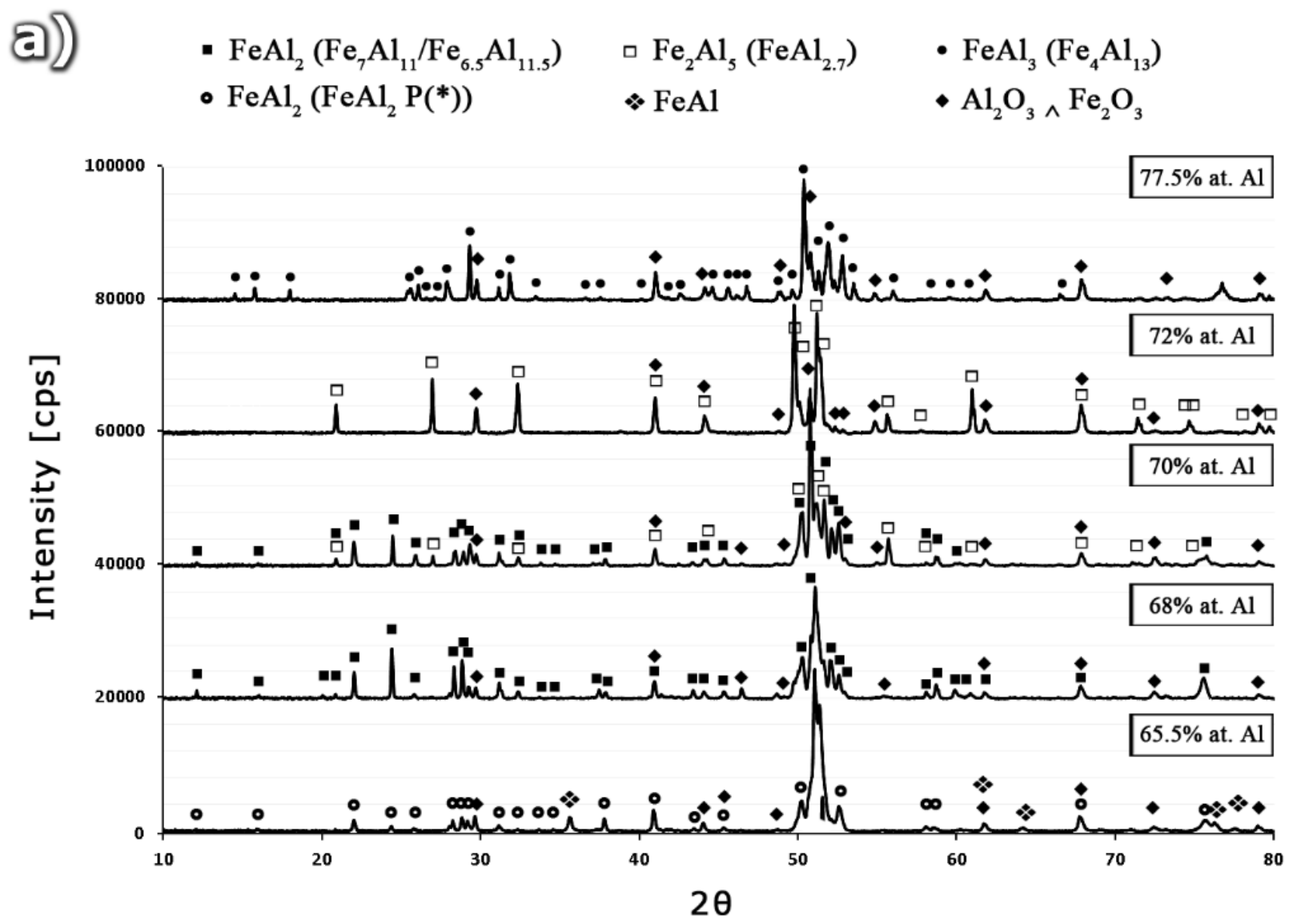

Figure 5. Cont. 


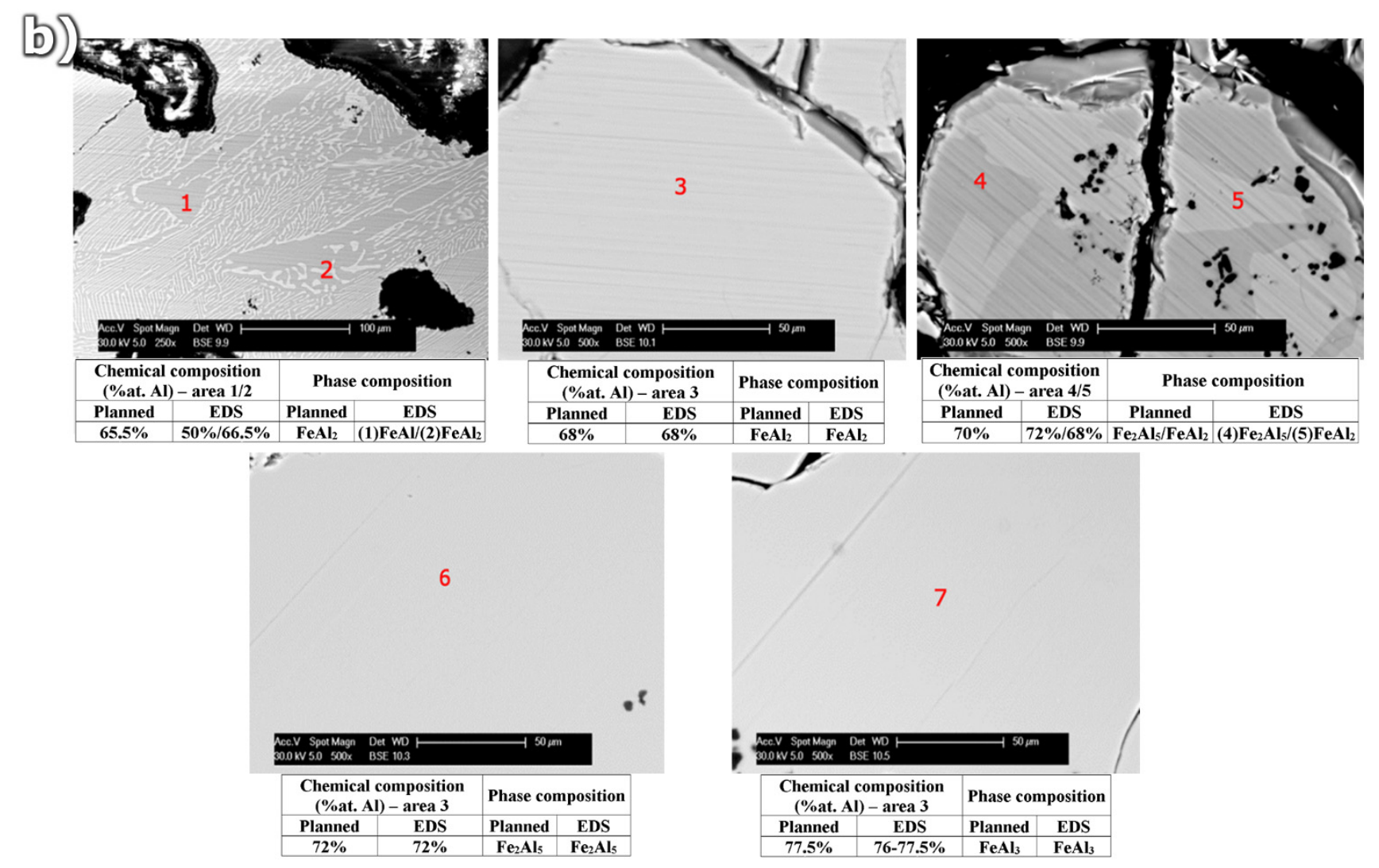

Figure 5. (a) The XRD patterns and (b) microstructure of alloys form Fe-Al system for various $\mathrm{Al}$ content $65.5 \mathrm{at} \%, 68 \mathrm{at} \%, 70 \mathrm{at} \%, 72$ at $\%$ and $77.5 \mathrm{at} \%$, as casted and annealed at temperature of $1050{ }^{\circ} \mathrm{C}$ for $100 \mathrm{~h}$.

The XRD patterns for samples with 70 at $\%$ consist of peaks coming from a mixture of $\mathrm{FeAl}_{2}+\mathrm{Fe}_{2} \mathrm{Al}_{5}$ phases, what is in agreement with the equilibrium system (Figure 2), as proposed by Kubaschewski [15] and others [17-20]. Whereas, the alloy containing 65.5 at $\%$ Al was identified as a mixture of $\mathrm{FeAl}+\mathrm{FeAl}_{2}$. It should be noted that in the case of the sample containing 65.5 at $\% \mathrm{Al}$, diffraction peaks are most closely related to the data included in the PDF file (00-033-0019) [41] described as $\mathrm{FeAl}_{2}$. In the other samples (identified by EDS as $\mathrm{FeAl}_{2}$ ) with aluminum content increasing to 68 and $70 \mathrm{at} \%$, the identification of peaks allows for their assignment to $\mathrm{Fe}_{7} \mathrm{Al}_{11}$ (01-073-2520) [42] and $\mathrm{Fe}_{6.5} \mathrm{Al}_{11.5}$ (04-007-1136), respectively [42]. The possibility of assigning the reflections originating from the same phase with slightly different aluminum content to different PDF files of different position, different intensity and different symmetry of reflections (Figure 6) is an indirect proof of the need to arrive at a clear crystallographic description of the phase, dependent on both the content of the constituent elements and the temperature [40-46]. Such work, involving the indexing of diffraction reflections from the obtained from Al-rich phases, including $\mathrm{Fe}_{2} \mathrm{Al}_{5}$ and $\mathrm{FeAl}_{3}$, using different methods (e.g., DICVOL66, ITO, N-TREOR), will be discussed in a separate publication. 


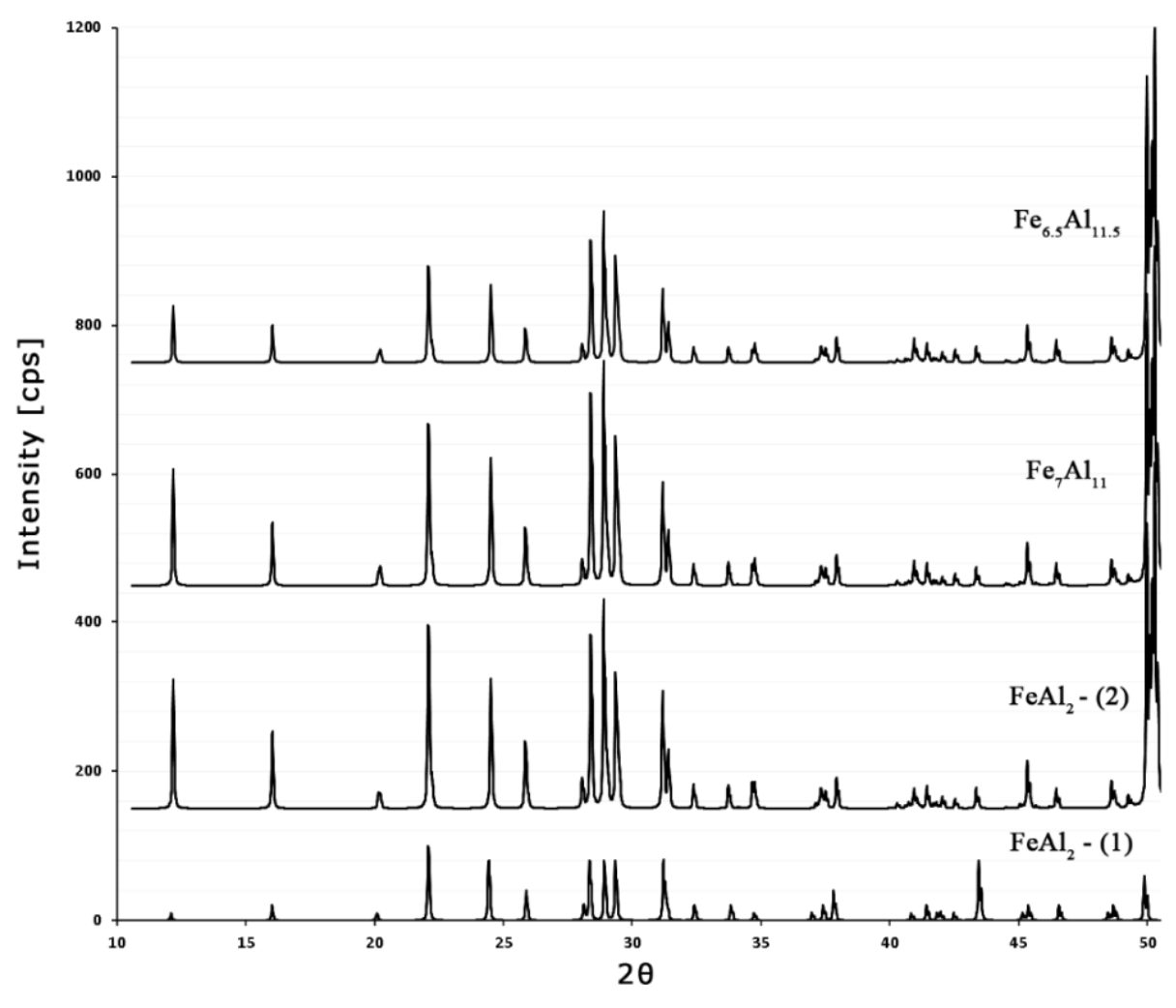

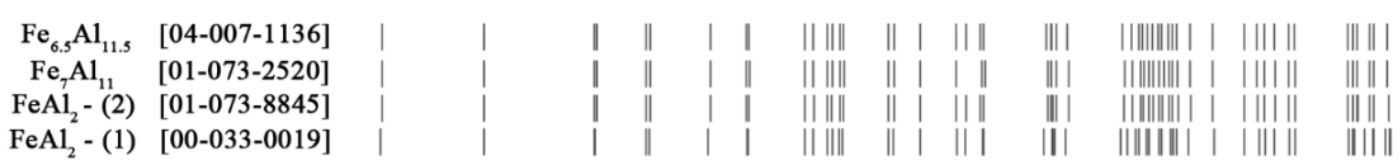

Figure 6. Different PDF files for $\mathrm{FeAl}_{2}$ phase with visible differences of diffraction peak positions and their intensity.

\subsection{Mechanical Properties Test}

Ambiguous, and above all, very few structural descriptions of the analyzed Al-rich $\mathrm{FeAl}_{2}, \mathrm{Fe}_{2} \mathrm{Al}_{5}$ and $\mathrm{FeAl}_{3}$ phases are also the reason for the small interest on the utility (structural or functional) of alloys containing these phases, and thus the lack of information about their properties, mostly mechanical. The literature only provides the hardness values of the Al-rich intermetallic phases, which are depended on the applied load, the method of preparation, the chemical composition and the macroscopic geometrical dimensions [24-29,39,40]. The intermetallic hardness value exists in the wide range of value, respectively, 900-1050 $\mathrm{HV}$ for $\mathrm{FeAl}_{2}, 950-1100 \mathrm{HV}$ for $\mathrm{Fe}_{2} \mathrm{Al}_{5}$ and 800-980 $\mathrm{HV}$ for $\mathrm{FeAl}_{3}$ [25-28]. Such wide ranges of hardness for structures with a narrow range of chemical composition, which are not subjected to allotrope changes, are highly ambiguous. Therefore, in order to mutually compare the hardness of the Al-rich phases produced by means of melting and casting, undergoing homogenization, their hardness was determined using the Mayer's law and the law of variable hardness for the hypothetical diagonal print of $20 \mu \mathrm{m}$ (Figure 7) [30].

The values obtained, measured on the phase-homogeneous ingots with a diameter of $30 \mathrm{~mm}$ and the height of $100 \mathrm{~mm}$ are noticeably lower, especially in the case of the $\mathrm{FeAl}_{3}$ phase than the literature data and are, respectively, $892 \pm 6 \mathrm{HV}$ for $\mathrm{FeAl}_{2}, 903 \pm 7 \mathrm{HV}$ for $\mathrm{Fe}_{2} \mathrm{Al}_{5}$, and $691 \pm 5 \mathrm{HV}$ for $\mathrm{FeAl}_{3}$. 


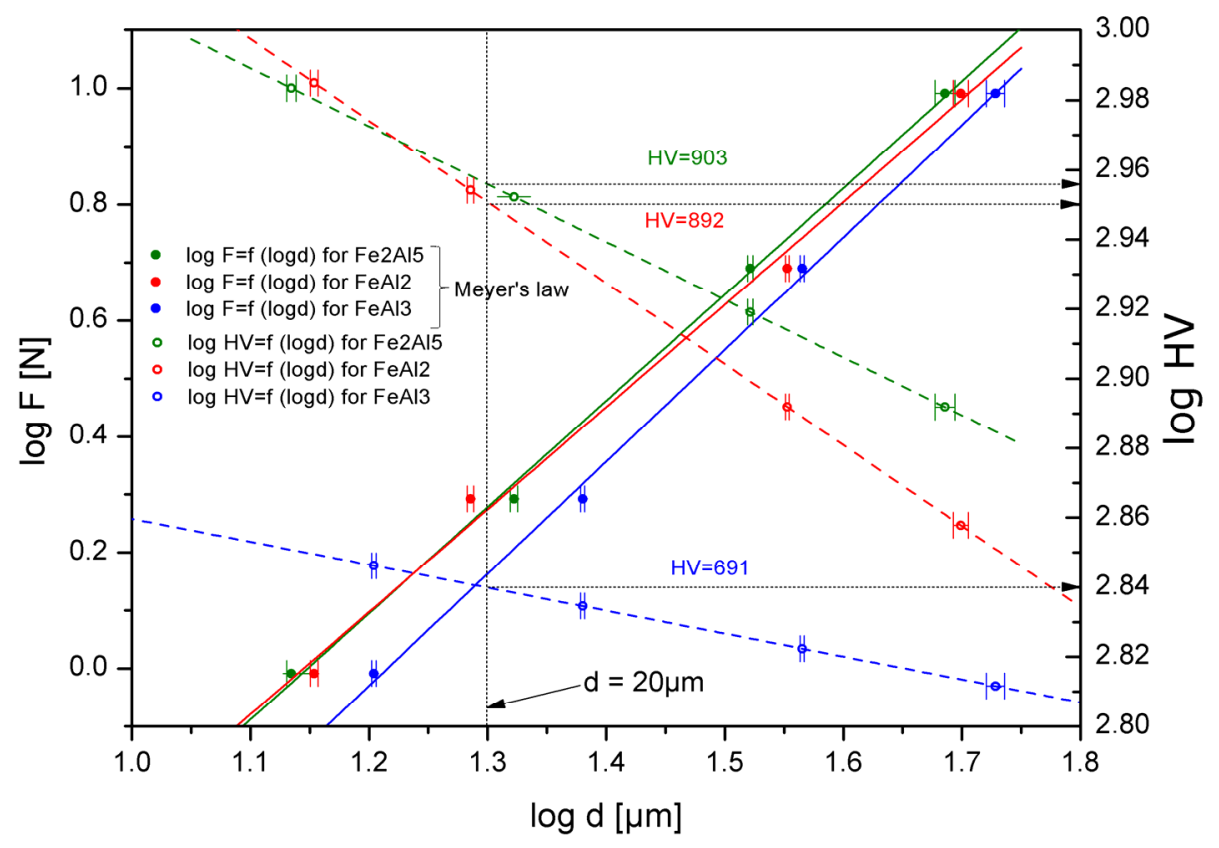

Figure 7. Hardness of Al-rich phases determined for hypothetical diagonal of indentation, which equals $20 \mu \mathrm{m}$.

The microhardness measurements, in particular the clear and measurable cracks propagating from the corner prints (Figure 8) made it possible to assess the mechanical properties of the analyzed subsequent Al-rich phases form the Fe-Al system, in particular:

Stress intensity factor $\mathrm{K}_{1 \mathrm{C}}[47,48]$ :

$$
\mathrm{K}_{1 \mathrm{C}}=0.0937 \times\left[\mathrm{H}_{0}\left(\mathrm{P}-\mathrm{P}_{0}\right) / 41\right]^{1 / 2}
$$

where $\mathrm{H}_{0}$ - Vickers hardness (load-independent microhardness); $\mathrm{P}$-Indentation load; $\mathrm{P}_{0}$ - threshold indentation load for cracking; 1-The length of the diagonal indentation.

Fragility factor $\mathrm{I}_{\mathrm{b}}[49]$ :

$$
\mathrm{I}_{\mathrm{b}}=\mathrm{HV} / \mathrm{K}_{1 \mathrm{C}}
$$

where $\mathrm{HV}$-Vickers hardness; $\mathrm{K}_{1 \mathrm{C}}$ - Stress intensity factor.

The threshold force of the indenter $\mathrm{P}^{*}[49]$ :

$$
\mathrm{P}^{*}=1.6 \times 10^{4} \times \mathrm{K}_{1 \mathrm{C}}\left(\mathrm{K}_{1 \mathrm{C}} / \mathrm{HV}\right)^{3}
$$

where HV—Vickers hardness; $\mathrm{K}_{1 \mathrm{C}}$ - Stress intensity factor.

Plastic deformation zone radius b [49]:

$$
\mathrm{b}=0.69 \times \mathrm{a} \times(\mathrm{E} / \mathrm{HV})^{0.5}
$$

where a-The length of the crack; HV—Vickers hardness; E-Young's modulus. 

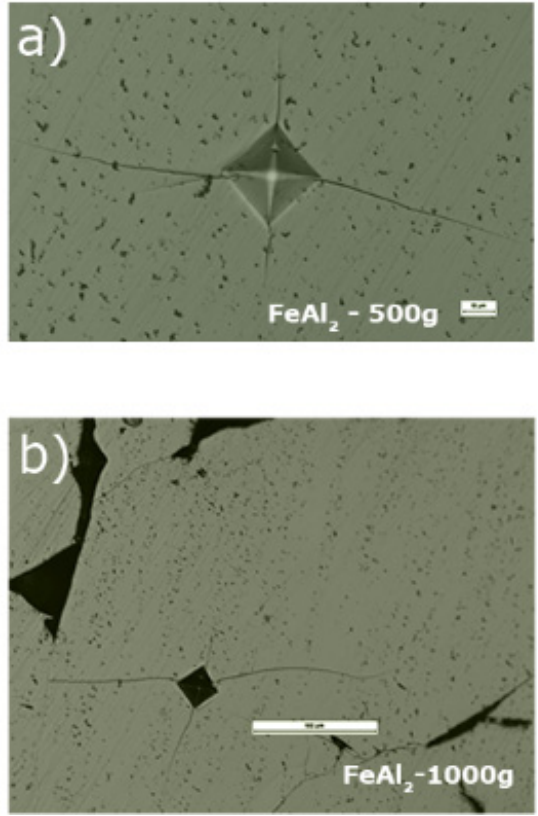
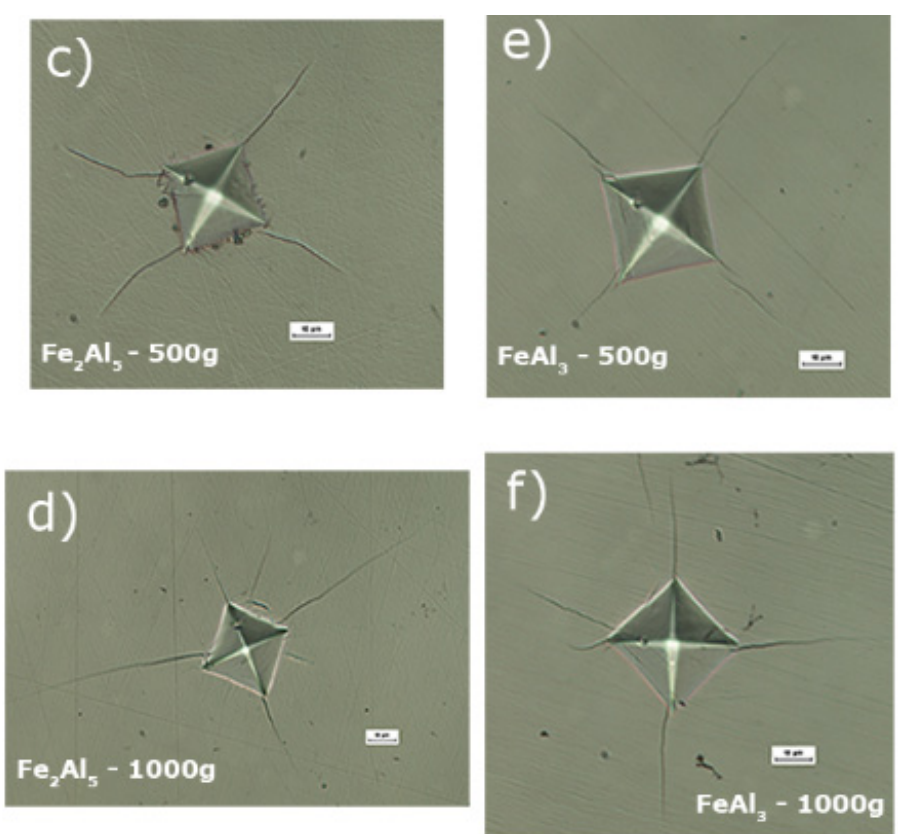

Figure 8. Indentations after Vickers hardness tests with propagating cracks observed for $\mathrm{FeAl}_{2}(\mathbf{a}, \mathbf{b}) ; \mathrm{Fe}_{2} \mathrm{Al}_{5}(\mathbf{c}, \mathbf{d}) ;$ and $\mathrm{FeAl}_{3}(\mathbf{e}, \mathbf{f})$ phases.

However, for the quantitative assessment of these parameters, it is necessary to know the basic parameter characteristic for each type of material, namely, the Young's modulus. The value of this parameter was determined by the nano-indentation Vickers indenter, assuming a constant Poisson's ratio at the level of $v=0.3[29,50-53]$. In this method, the value of the Young's modulus is defined as the value of the slope of the tangent to the force recorded during the unloading the indenter (Figure 9) [30,48,49].
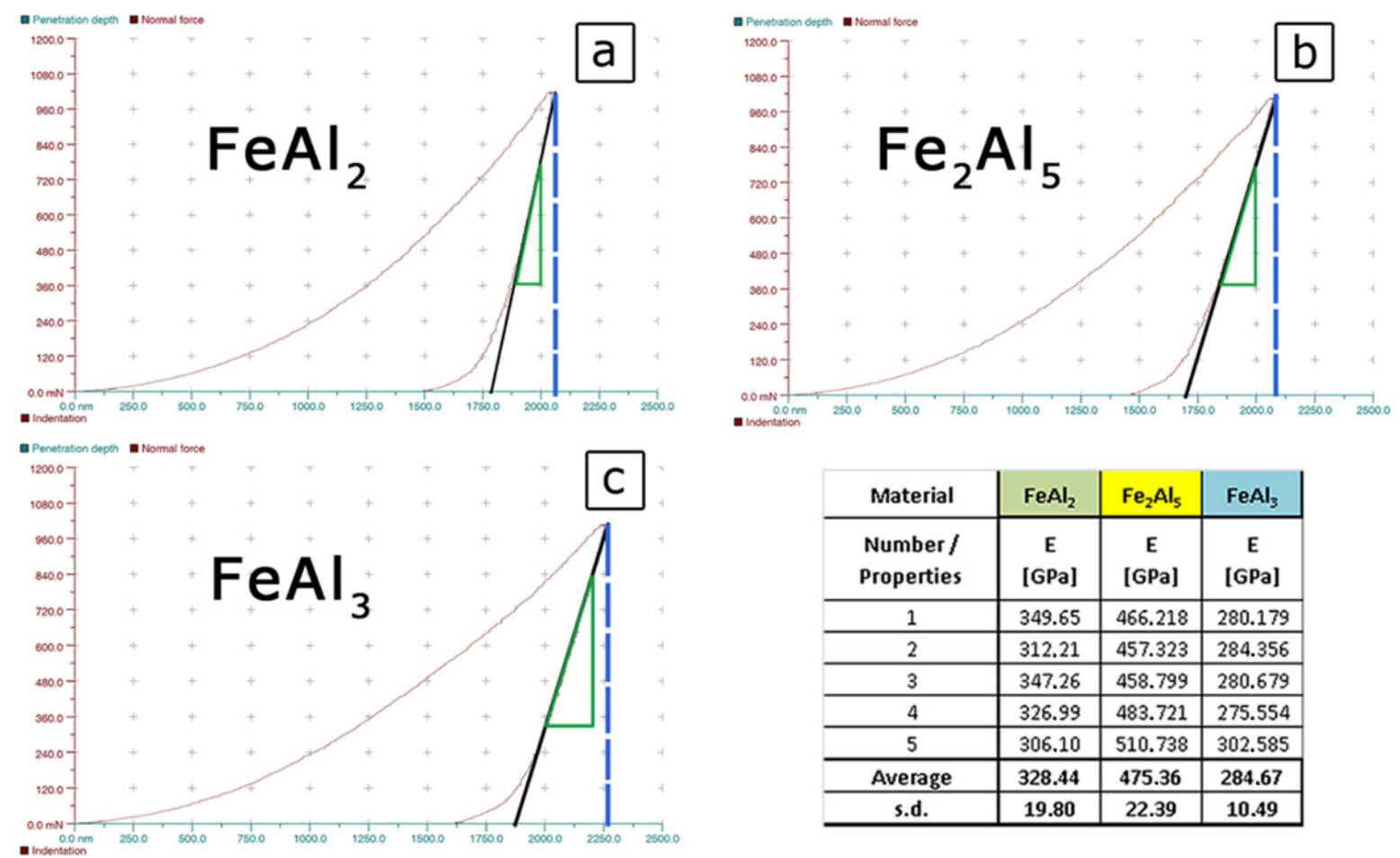

\begin{tabular}{c|c|c|c|}
\hline Material & $\mathrm{FeAl}_{2}$ & $\mathrm{Fe}_{2} \mathrm{Al}_{5}$ & $\mathrm{FeAl}_{3}$ \\
\hline $\begin{array}{c}\text { Number/ } \\
\text { Properties }\end{array}$ & $\begin{array}{c}\mathrm{E} \\
{[\mathrm{GPa}]}\end{array}$ & $\begin{array}{c}\mathrm{E} \\
{[\mathrm{GPa}]}\end{array}$ & $\begin{array}{c}\mathrm{E} \\
{[\mathrm{GPa}]}\end{array}$ \\
\hline 1 & 349.65 & 466.218 & 280.179 \\
\hline 2 & 312.21 & 457.323 & 284.356 \\
\hline 3 & 347.26 & 458.799 & 280.679 \\
\hline 4 & 326.99 & 483.721 & 275.554 \\
\hline 5 & 306.10 & 510.738 & 302.585 \\
\hline Average & 328.44 & 475.36 & $\mathbf{2 8 4 . 6 7}$ \\
\hline s.d. & 19.80 & 22.39 & $\mathbf{1 0 . 4 9}$ \\
\hline & & & \\
\hline
\end{tabular}

Figure 9. The results of Young's modulus measurement for $\mathrm{FeAl}_{2}$ (a); $\mathrm{Fe}_{2} \mathrm{Al}_{5}$ (b); and $\mathrm{FeAl}_{3}(\mathbf{c})$ phases obtained by instrumented indentation. 
The obtained values are respectively: $328 \pm 20 \mathrm{GPa}$ for $\mathrm{FeAl}_{2}, 475 \pm 22 \mathrm{GPa}$ for $\mathrm{Fe}_{2} \mathrm{Al}_{5}$ and $284 \pm 10 \mathrm{GPa}$ for $\mathrm{FeAl}_{3}$ which, at the spreading of the results at a level of $6 \%$, indirectly proves high homogeneity, and thus a single-phase structure of the test samples.

The prints obtained when measuring hardness at the loads of $500 \mathrm{~g}$ and $1000 \mathrm{~g}$, characterized by a grid of cracks occurring at the corners (Figure 9a-f), were used to determine the stress intensity factor which is a measure of the fracture toughness. The observation of the micro areas in the corners most likely indicates the Palmqvist cracks which are characteristic for ceramic materials or cermets i.e., $\mathrm{Si}_{3} \mathrm{~N}_{4}, \mathrm{~B}_{4} \mathrm{C}$, WC-Co, $\mathrm{ZrO}_{2}$ [53-55]. They are visible in the case of the $\mathrm{FeAl}_{2}, \mathrm{FeAl}_{3}$, and $\mathrm{Fe}_{2} \mathrm{Al}_{5}$ phases in the range of a load equal to $500 \mathrm{~g}$ (Figure 9a,c,f). Observed cracks take the form of short lines extending from the corners into the deformed zone. Moreover, in the case of $1000 \mathrm{~g}$ load (Figure 9b,d,e) well-visible additional lateral cracks of different lengths appear within the cracks' area. There were, however, no branched cracks, typical for brittle ceramics, coming from the corners or sides of the recesses.

Indentation fracture toughness was calculated following reference [47] where the authors for the first time reported the existence of the compressive stresses core zone in the intermetallic compounds. Song and Varin [47] concluded that the most reasonable values of indentation fracture toughness for intermetallic compounds were obtained from the Palmqvist-type cracking using modified Shetty et al. model [48] modified by Song and Varin [47] for the indentation size effect (ISE).

The obtained values of this parameter for each of the studied iron aluminides amounted to: $0.592 \pm 0.003 \mathrm{MPa} / \mathrm{m}^{0.5}$ for $\mathrm{FeAl}_{2}, 0.817 \pm 0.004 \mathrm{MPa} / \mathrm{m}^{0.5}$ for $\mathrm{Fe}_{2} \mathrm{Al}_{5}$ and $0.967 \pm 0.005 \mathrm{MPa} / \mathrm{m}^{0.5}$ for $\mathrm{FeAl}_{3}$. The authors also drew attention to the dependence [49] determining the fragility "Ib" factor (2), which is the ratio of hardness, on the fracture toughness, specifying the theoretical nature of the observed cracks. The relationship expressing the threshold force of the " $\mathrm{P}$ *" indenter (3) was also determined. This threshold force is the measure of cleavage allowing designing ceramic materials, i.e., to control the level of strength of materials by controlling the hardness of the material or fracture toughness, for example, by introducing particulates impeding the development of cracks. The values for both of the factors are comparable to the values obtained for alundum ceramics $\left(\mathrm{Al}_{2} \mathrm{O}_{3}\right)$ and are as follows: $1.40 \pm 0.020 \mu \mathrm{m}^{-0.5}$ for $\mathrm{FeAl}_{2}, 0.92 \pm 0.016 \mu \mathrm{m}^{0.5}$ for $\mathrm{Fe}_{2} \mathrm{Al}_{5}$ and $0.70 \pm 0.011 \mu \mathrm{m}^{-0.5}$ for $\mathrm{FeAl}_{3}$ in the case of the fragility factor. In contrast, the threshold indentation force for $\mathrm{FeAl}_{2}$ is $3.4 \pm 0.2 \mathrm{~N}$, $\mathrm{Fe}_{2} \mathrm{Al}_{5}-16.3 \pm 0.9 \mathrm{~N}$ and for $\mathrm{FeAl}_{3}-43.9 \pm 2.2 \mathrm{~N}$.

On the basis of the measurements and microscopic observations the " $b$ " plastic deformation zone radius (4) was also evaluated. Usually, the main and side cracks run through it, and the zone is characterized by significant movements of the material and the large amount of short microcracks. Its size depends primarily on the brittleness of the material and is determined by the ratio of the hardness to the Young's modulus or the ratio of the hardness to the values of the fracture toughness. Therefore it is associated with the development of cracks as a function of the size of the load, which determines the type of observed cracks. The highest value of this parameter was found for $\mathrm{FeAl}_{2}-81.1 \pm 0.9 \mu \mathrm{m}$, then for $\mathrm{FeAl}_{3}-75.4 \pm 0.7 \mu \mathrm{m}$ and the radius of the plastic deformation zone for $\mathrm{Fe}_{2} \mathrm{Al}_{5}$ was estimated at $62.2 \pm 0.9$ microns. 


\subsection{Discussion}

Difficulties with the correct and unambiguous property determination of the $\mathrm{FeAl}_{2}, \mathrm{Fe}_{2} \mathrm{Al}_{5}$ and $\mathrm{FeAl}_{3}$ phases are mainly due to a slight difference in the aluminum concentration from $\mathrm{FeAl}_{1.76}$ to $\mathrm{FeAl}_{3.25}$. However, the difference in the aluminum concentration in conjunction with the low symmetry of the crystal arrangement of these phases and similar enthalpy of formation [40], determines substantially small, but measurable differences in the size of their strength parameters. Therefore, in order to obtain single-phase Al-rich structures, the alloys with specific and a very narrow range of chemical compositions, using the long-term homogenization process following the melting and casting, must be fabricated [29,52]. The lack of order and the semi-metallic [24] spin-glass [31] nature, also determined as quasi-amorphous [46], based on the nature of the crystal structure of these phases and the cardinality of atoms, put into question the applicability of the $\mathrm{FeAl}_{2}, \mathrm{Fe}_{2} \mathrm{Al}_{5}$ and $\mathrm{FeAl}_{3}$ phases despite their recently relatively well-recognized thermal and magnetic properties [31,44,46]. However, on the other hand, the determined mechanical properties of the Al-rich phases of the Fe-Al system, related to the lack of order of the crystal arrangement [29,52] locate them on the borderline of technical ceramics, glasses, and composite materials which can include, inter alia, nitrides and oxides of aluminum, or titanium oxides and molybdenum and boron carbide (Figure 10) (Table 1).

The analysis of the technological processes and the sought of the Al-rich phases applications provide for the greatest prospect of their use in the area of welding and the production of heat-resistant barrier coatings [56,57]. However, the potential area of their application may be changed at the time of acquiring comprehensive knowledge of the structural and strength properties determining their possible applications.

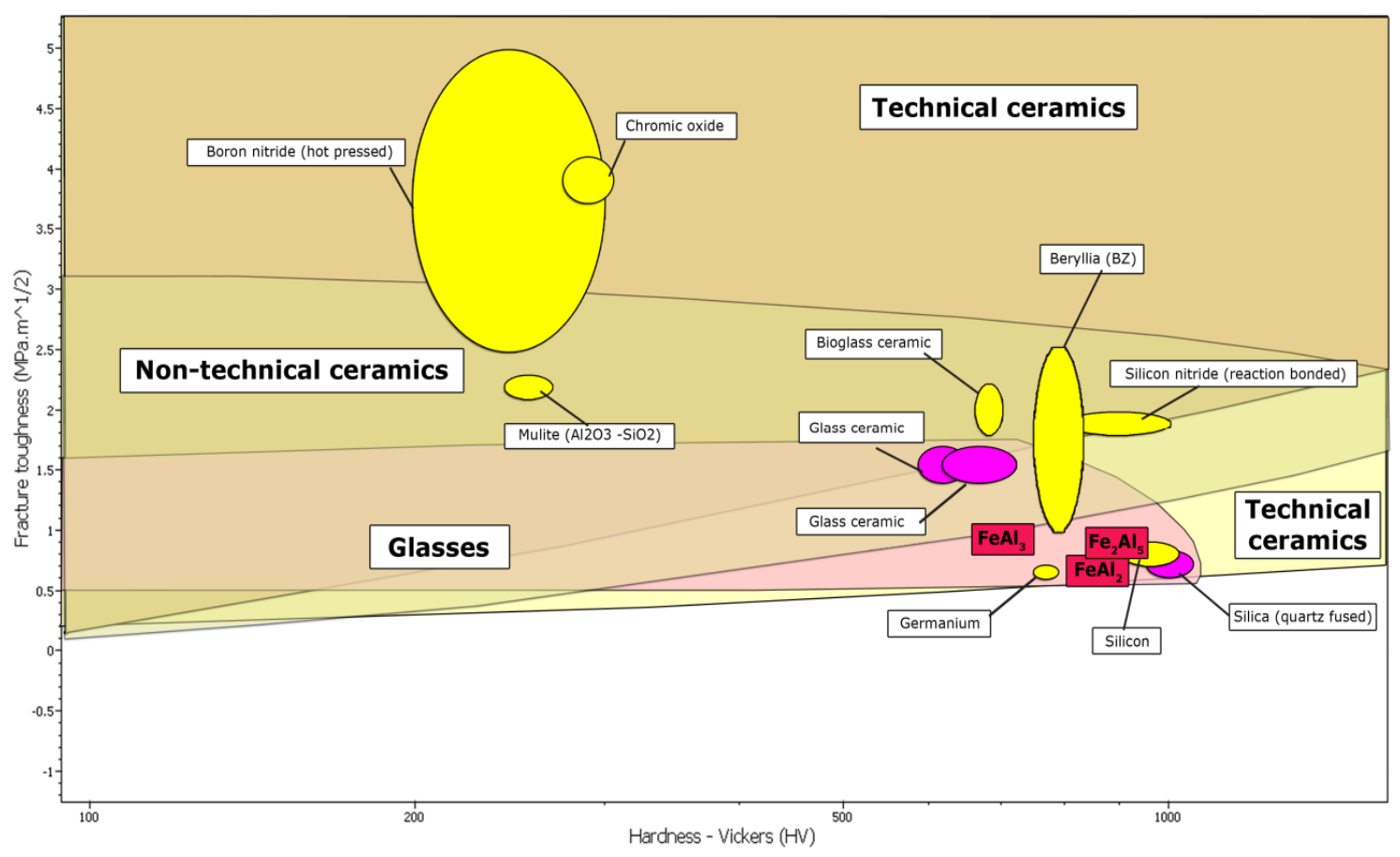

Figure 10. The comparison of mechanical properties for Al-rich $\mathrm{FeAl}_{2}, \mathrm{Fe}_{2} \mathrm{Al}_{5}$ and $\mathrm{FeAl}_{3}$ phases with the others materials. 
Table 1. The comparison of mechanical properties for $\mathrm{Al}$-rich $\mathrm{FeAl}_{2}, \mathrm{Fe}_{2} \mathrm{Al}_{5}$ and $\mathrm{FeAl}_{3}$ phases with the others materials.

\begin{tabular}{ccccccccc}
\hline $\begin{array}{c}\text { Material/ } \\
\text { Properties }\end{array}$ & $\begin{array}{c}\mathbf{H V} \\
{[\mathbf{G P a}]}\end{array}$ & $\begin{array}{c}\mathbf{E} \\
{[\mathbf{G P a}]}\end{array}$ & $\begin{array}{c}\mathbf{V} \\
{[-]}\end{array}$ & $\begin{array}{c}\mathbf{K}_{\mathbf{1 C}} \\
{\left[\mathbf{M P a} / \mathbf{m}^{0.5}\right]}\end{array}$ & $\begin{array}{c}\mathbf{I b} \\
{\left[\boldsymbol{\mu \mathbf { m } ^ { - 0 . 5 } ]}\right.}\end{array}$ & $\begin{array}{c}\mathbf{P}^{*} \\
{[\mathbf{N}]}\end{array}$ & $\begin{array}{c}\mathbf{b} \\
{[\boldsymbol{\mu m}]}\end{array}$ & ref. \\
\hline Diament & 81 & $1000-1200$ & $0.07-0.2$ & 5.3 & 15.00 & 0.02 & - & {$[49,54,55]$} \\
$\mathrm{Al}_{2} \mathrm{O}_{3}$ & $14-18$ & $360-420$ & $0.22-0.25$ & $3-5$ & 4.00 & 1.0 & - & {$[49,54,55]$} \\
$\mathrm{SiC}$ & $18-25$ & $340-450$ & $0.18-0.19$ & 3 & 7.20 & 0.13 & - & {$[49,54,55]$} \\
$\mathrm{Steel}$ & $1.6-5.0$ & $190-210$ & $0.240-0.300$ & $50-210$ & 0.014 & $0.1 \times 10^{9}$ & - & {$[49,54,55]$} \\
$\mathrm{Cu}$ & $0.1-0.8$ & $100-124$ & $0.310-0.340$ & 100 & 0.008 & $3 \times 10^{9}$ & - & {$[49,54,55]$} \\
$\mathrm{Al}$ & $0.1-0.4$ & $69-71$ & $0.260-0.360$ & 350 & 0.001 & $4 \times 10^{12}$ & - & {$[49,54,55]$} \\
$\mathrm{WC}-\mathrm{Co}$ & $12-20$ & $540-610$ & $0.280-0.300$ & $7-28$ & 1.10 & 170 & - & {$[54,58]$} \\
$\mathrm{NiAl}$ & $2.7-5.3$ & $100-310$ & $0.23-0.45$ & $4-6$ & 0.50 & 110 & - & {$[58-60]$} \\
$\mathrm{Ni}_{3} \mathrm{Al}$ & $3.5-4.5$ & $100-300$ & $0.2-0.35$ & $30-40$ & 0.10 & $14 \times 10^{4}$ & - & {$[61,62]$} \\
$\mathrm{Fe}_{3} \mathrm{Al}$ & $2.5-3.5$ & 150 & $0.290-0.400$ & $25-35$ & 0.12 & $30 \times 10^{4}$ & - & {$[50-53]$} \\
$\mathrm{FeAl}$ & $4-5.2$ & 260 & $0.300-0.310$ & $8-15$ & 2.88 & 2875 & - & {$[50-57]$} \\
$\mathrm{FeAl}_{2}$ & $9-10.5$ & 475 & 0.300 & 3.88 & 2.71 & 4 & 81 & {$[$ this study] } \\
$\mathrm{Fe}_{2} \mathrm{Al} l_{5}$ & $9.5-11$ & 284 & 0.300 & 5.17 & 2.13 & 9 & 62 & {$[$ this study] } \\
$\mathrm{FeAl}_{3}$ & $8-9.8$ & 328 & 0.300 & 4.92 & 1.99 & 13 & 75 & {$[$ this study] } \\
\hline
\end{tabular}

\section{Experimental Section}

In order to characterize the mechanical properties of the Al-rich phases, it was necessary to determine the content of aluminum allowing independent occurrence of these phases, without the possible (according to the equilibrium system (Figure 2)) presence of crystal mixtures. The problem has been solved by fabrication of the sample sets with various Al-content in the range from 56 at $\%$ $\left(\mathrm{FeAl}_{3}+\mathrm{FeAl}_{2}\right)$ to 80 at $\%\left(\mathrm{FeAl}_{3}+\mathrm{Al}(\mathrm{Fe})\right)$, using powder metallurgy of elementary components of iron and aluminum. Technically pure iron and aluminum powders were used for green body fabrication with a diameter of $20 \mathrm{~mm}$ and a height $10 \mathrm{~mm}$, using the technique of uniaxial compression at ambient temperature under the pressure of $700 \mathrm{MPa}$. Then the samples were sintered at $1100{ }^{\circ} \mathrm{C}$ for approx. $2 \mathrm{~h}$. The sintered material was homogenized at $1050{ }^{\circ} \mathrm{C}$ for $24 \mathrm{~h}$ in a vacuum after prior flushing the chamber with argon. The samples with single-phase structure were used to specify the aluminum content determining the presence of only one particular Al-rich phase. Further study of the mechanical properties of single-phase intermetallic alloys obtained by powder metallurgy was impossible due to the inherent presence of a structure made of sinters of elementary powders of oxide phases.

To investigate mechanical properties of single-phase alloys with chemical composition evaluated during sintering process, the other set of samples were made by melting and casting in a vacuum induction melting furnace Balzers VSG10. Then these samples were homogenized by annealing at $1200{ }^{\circ} \mathrm{C}$ for $100 \mathrm{~h}$.

The samples obtained, both using powder metallurgy and melting and casting, were subjected to structural analysis (SEM, EDS) on the 3D Quanta FEG Dual Beam microscope. The phase identification was carried out using Rigaku Ultima IV diffractometer with cobalt target (i.e., monochromatic radiation with a wavelength of $0.17889 \mathrm{~nm}$ was used). The analysis was conducted within the $2 \theta$ range of $20^{\circ}-70^{\circ}$, at a scanning speed of $0.02^{\circ} / \mathrm{min}$. 
The final samples of single-phase structure obtained by melting and casting were used for the measurement of the microhardness carried out with Shimadzu type M Microhardness Tester at loads of $100 \mathrm{~g}, 500 \mathrm{~g}, 1000 \mathrm{~g}$, in agreement with variable hardness law, for $10 \mathrm{~s}$. Using the Nanoindentation Tester NHT Young's modulus was determined for the Al-rich phases by analyzing changes in the load (500 $\mathrm{g}$ and $1000 \mathrm{~g}$ ) with a change in the penetration depth of the indenter.

The micro-cracks observed in the corners of indentations were used to determine the critical stress intensity factor $\mathrm{K}_{1 \mathrm{C}}$, which is a measure of the fracture toughness [30,48,49,54-62]. The collected information allowed us to compare the properties of the obtained Al-rich single-phases intermetallic alloys with other structural intermetallics, brittle ceramic materials and the classic construction materials.

\section{Conclusions}

The results of microstructure investigation, in the area of Al-rich phases presence, showed the discrepancy of results in the phase identification already published. Moreover, due to realized structure analysis and observed phase transformation, the authors suggest different $\mathrm{Al}$ concentration for $\mathrm{FeAl}_{2}$, $\mathrm{Fe}_{2} \mathrm{Al}_{5}$ and $\mathrm{FeAl}_{3}$ phases.

The hardness, Young's modulus and fracture toughness results of homogeneous intermetallic materials, such as $\mathrm{FeAl}_{2}\left(\mathrm{Fe}_{6.5} \mathrm{Al}_{11.5}\right), \mathrm{Fe}_{2} \mathrm{Al}_{5}\left(\mathrm{FeAl}_{2.7}\right)$ and $\mathrm{FeAl}_{3}\left(\mathrm{Fe}_{4} \mathrm{Al}_{13}\right)$, are in good agreement with proposed phase transformation and phase identification.

On the base of obtained results, the authors suggest that the problem with Al-rich intermetallic phases implementation is not related to the luck of potential application. It is rather connected with rather poor knowledge about their structure and mechanical properties, which still require further investigation.

\section{Acknowledgments}

This work was supported by a grant from the project system Provincial Government of Mazovia in Poland (No. 249/ES/ZS-III/W-POKL/14), which is gratefully acknowledged, and Faculty of Advanced Technologies and Chemistry, Military University of Technology.

\section{Author Contributions}

Piotr Matysik initiated the overall research concept and supervised the research work, completed the initial and final manuscript, managed experimental work and performed all measurements; Stanisław Jóźwiak supervised the research work, completed the initial and final manuscript and revised critically the content of the paper; Tomasz Czujko supervised the research work, completed the initial and final manuscript and revised critically the content of the paper.

\section{Conflicts of Interest}

The authors declare no conflict of interest. 


\section{References}

1. Gu, J.; Gu, S.; Xue, L.; Wu, S.; Yan, Y. Microstructure and mechanical properties of in situ $\mathrm{Al}_{13} \mathrm{Fe}_{4} / \mathrm{Al}$ composites prepared by mechanical alloying and spark plasma sintering. Mater. Sci. Eng. 2012, 558, 684-691.

2. Iizadi, S.; Akbaria, G.H.; Janghorba, K. Sintering and mechanical properties of mechanically alloyed Fe-Al-(B) nanostructures. J. Alloys Compd. 2010, 496, 699-702.

3. D’Angelo, L.; D’Onofrio, L.; Gonzalez, G. Nanophase intermetallic FeAl obtained by sintering after mechanical alloying. J. Alloys Compd. 2009, 483, 154-158.

4. Jóźwiak, S.; Karczewski, K. Influence of aluminum oxides on abrasive wear resistance of Fe-50 at\% Al intermetallic sinters. J. Alloys Compd. 2009, 482, 405-411.

5. Novák, P.; Knotek, V.; Voděrová, M.; Kubásek, J.; Šerák, J.; Michalcová, A.; Vojtěch, D. Intermediary phases formation in Fe-Al-Si alloys during reactive sintering. J. Alloys Compd. 2010, 497, 90-94.

6. Matysik, P.; Jozwiak, S.; Czujko, T. The kinetics of non-isothermal iron and aluminum powder mixtures sintering in protective atmosphere. J. Alloys Compd. 2013, 549, 92-99.

7. Novák, P.; Michalcová, A.; Marek, I.; Mudrová, M.; Saksl, K.; Bednarcík, J.; Zikmund, P.; Vojtěch, D. On the formation of intermetallics in Fe-Al system-An in situ XRD study. Intermetallics 2013, 32, 127-136.

8. Pocheć, E.; Jóźwiak, S.; Karczewski, K.; Bojar, Z. Fe-Al phase formation around SHS reactions under isothermal conditions. J. Alloys Compd. 2011, 509, 1124-1128.

9. Nicula, R.; Turquier, F.; Stir, M.; Kodash, V.Y.; Groza, J.R.; Burkel, E. Quasicrystal phase formation in Al-Cu-Fe nanopowders during field-activated sintering (FAST). J. Alloys Compd. 2007, 434-435, 319-323.

10. Krasnowski, M.; Kulik, T. Bulk amorphous and nanocrystalline $\mathrm{Al}_{83} \mathrm{Fe}_{17}$ alloys prepared by consolidation of mechanically alloyed amorphous powder. J. Alloys Compd. 2010, 495, 382-385.

11. Durejko, T.; Lipiński, S.; Bojar, Z.; Bystrzycki, J. Processing and characterization of graded metal/intermetallic materials: The example of Fe/FeAl intermetallics. Mater. Des. 2011, 32, $2827-2834$.

12. Senderowski, C.; Bojar, Z.; Wołczyński, W.; Pawłowski, A. Microstructure characterization of D-gun sprayed Fe-Al intermetallic coatings. Intermetallics 2009, 18, 1405-1409.

13. Senderowski, C.; Bojar, Z.; Wołczyński, W.; Roy, G.; Czujko, T. Residual stresses determined by the modified Sachs method within a gas detonation sprayed coatings of the Fe-Al intermetallic. Arch. Metall. Mater. 2007, 52, 569-578.

14. Wang, L.; Yan, D.; Dong, Y.; Zhang, J.; Chen, X. Nanostructured ceramic composite coating prepared by reactive plasma spraying micro-sized $\mathrm{Al}-\mathrm{Fe}_{2} \mathrm{O}_{3}$ composite powders. Ceram. Int. 2013, 39, 2437-2442.

15. Kubaschewski, O.; Dench, W.A. The heats of formation in the systems titanium-aluminium and titanium-iron. Acta Metall. 1955, 3, 339-346.

16. Kattner, U.R.; Burton, B.P. Al-Fe (Aluminum-Iron). In Phase Diagrams of Binary Alloys; Okamoto, H., Ed.; ASM International: Material Park, OH, USA, 1993; pp. 12-28. 
17. Massalski, T.B. Binary Alloy Phase Diagrams, 2nd ed.; ASM International: Material Park, OH, USA, 1990; pp. 3401-3441.

18. Palm, M. Concepts derived from phase diagram studies for the strengthening of Fe-Al-based alloys. Intermetallics 2005, 13, 1286-1295.

19. Диаграммы Состояния—Phase Diagrams. Available online: http://steelcast.ru/equilibrium_diagram (accessed on 25 January 2014). (In Russian)

20. Ellner, M. Polymorphic phase transformation of $\mathrm{Fe}_{4} \mathrm{Al}_{13}$ causing multiple twinning with decagonal pseudo-symmetry. Acta Cryst. 1995, B51, 31-36.

21. Stein, F.; Vogel, S.C.; Eumann, M.; Palm, M. Determination of the crystal structure of the $\varepsilon$ phase in the Fe-Al system by high-temperature neutron diffraction. Intermetallics 2010, 18, 150-156.

22. Sundman, B.; Ohnuma, I.; Dupin, N.; Kattner, U.R.; Fries, S.G. An assessment of the entire Al-Fe system including D03 ordering. Acta Mater. 2009, 57, 2896-2908.

23. Phan, A.T.; Paek, M.K.; Kang, Y.B. Phase equilibria and thermodynamics of the Fe-Al-C system: Criticalevaluation, experiment and thermodynamic optimization. Acta Mater. 2014, 79, 1-15.

24. Chi, J.; Li, Y.; Vagizov, F.G.; Goruganti, V.; Ross, J.H., Jr. NMR and Mössbauer study of spin-glass behavior in $\mathrm{FeAl}_{2}$. Phys. Rev. B 2005, 71, doi:10.1103/PhysRevB.71.024431.

25. Ozaki, H.; Kutsuna, M.; Nakagawa, S.; Miyamoto, K. Laser roll welding of dissimilar metal joint of zinc coated steel to aluminum alloy. J. Laser Appl. 2010, 22, 1-6.

26. Rathod, M.J.; Katsuna, M. Joining of aluminum alloy 5052 and low-carbon steel by laser roll welding. Weld. J. 2004, 2, 16-26.

27. Potesser, M.; Schoeberl, T.; Antrekowitsch, H.; Bruckner, J. The characterization of the intermetallic Fe-Al layer of steel-aluminum weldings. In EPD Congress 2006; The Minerals, Metals \& Materials Society: San Antonio, TX, USA, 2006.

28. Shishkovsky, I.; Missemer, F.; Kakovkina, N.; Smurov, I. Intermetallics synthesis in the Fe-Al system via layer by layer 3D laser cladding. Crystals 2013, 3, 517-529.

29. Yousaf, M.; Iqbal, J.; Ajmal, M. Variables affecting growth and morphology of the intermetallic layer ( $\left.\mathrm{Fe}_{2} \mathrm{Al}_{5}\right)$. Mater. Characteriation 2011, 62, 517-525.

30. Pluta, Z.; Hryniewicz, T. Quantitative determination of material hardness. J. Quantum Inf. Sci. 2011, $1,127-134$.

31. Lue, C.S.; Oner, Y.; Naugle, D.G.; Ross, J.H., Jr. Spin glass behavior in FeAl2. Phys. Rev. B 2001, 63, doi:10.1103/PhysRevB.63.184405.

32. Shahverdi, H.R.; Ghomashchi, M.R.; Shabestari, S.; Hejazi, J. Microstructural analysis of interfacial reaction between molten aluminium and solid iron. J. Mater. Process. Technol. 2002, $124,345-352$.

33. Wang, D. Phase evolution of an aluminized steel by oxidation treatment. Appl. Surf. Sci. 2008, 254, 3026-3032.

34. Shiue, R.K.; Wu, S.K.; Lee, Y.L. Transient microstructure evolution of infrared brazed $\mathrm{Fe}_{3} \mathrm{Al}$ intermetallics using aluminium foil. Intermetallics 2005, 13, 818-826.

35. Karczewski, K.; Józwiak, S.; Chojnacki, M.; Bojar, Z. The influence of different additives on the kinetics of self-propagating high-temperature synthesis during the sintering process of $\mathrm{Fe}$ and $\mathrm{Al}$ elemental powders. Intermetallics 2010, 18, 1401-1404. 
36. Shen, P.Z.; He, Y.H.; Gao, H.Y.; Zou, J.; Xu, N.P.; Jiang, Y.; Huang, B.Y.; Liu, C.T. Development of a new graded-porosity FeAl alloy by elemental reactive synthesis. Desalination 2009, 249, 29-33.

37. Joslin, D.L.; Easton, D.S.; Liu, C.T.; Davis, S.A. Reaction synthesis of Fe-Al alloys. Mater. Sci. Eng. 1995, A192/193, 544-548.

38. Gedevanishvili, S.; Deevi, S.C. Processing of iron aluminides by pressureless sintering through $\mathrm{Fe}+\mathrm{Al}$ elemental route. Mater. Sci. Eng. 2002, A325, 163-176.

39. Hirose, S.; Itoh, T.; Makita, M.; Fujii, S.; Arai, S.; Sasaki, K.; Saka, H. Defect structure of deformed $\mathrm{Fe}_{2} \mathrm{Al}_{5}$ intermetallic compound. Intermetallics 2003, 11, 633-642.

40. Gąsior, W.; Dębski, A.; Moser, Z. Formation enthalpy of intermetallic phases from Al-Fe system measured with solution calorimetric method. Intermetallics 2012, 24, 99-105.

41. Bastin, G.F.; van Loo, F.J.J.; Vrolijk, J.W.G.A.; Wolff, L.R. Crystallography of aligned Fe-Al eutectoid. J. Crystal Growth 1978, 43, 745-751.

42. Corby, R.N.; Black, P.J. Structure of $\mathrm{FeAl}_{2}$ by anomalous dispersion methods. Acta Crystallogr. 1973, 29, 2669-2677.

43. Grin, J.; Burkhardt, U.; Ellner, M.; Peters, K. Refinement of the $\mathrm{Fe}_{4} \mathrm{Al}_{13}$ Structure and its relationship to quasihomological homotypical structures. Z. Kristallogr. 1994, 209, 479-487.

44. Popčević, P.; Smontara, A.; Ivkov, J.; Wencka, M.; Komelj, M.; Jeglič, P.; Vrtnik, S.; Bobnar, M.; Jagličić, Z.; Bauerr, B.; et al. Anisotropic physical properties of the $\mathrm{Al}_{13} \mathrm{Fe}_{4}$ complex intermetallic and its ternary derivative $\mathrm{Al}_{13}(\mathrm{Fe}, \mathrm{Ni})_{4}$. Phys. Rev. B 2010, 81, doi:10.1103/PhysRevB.81.184203.

45. Schubert, K.; Kluge, M. Über den Bindungszustand bei $\mathrm{Fe}_{2} \mathrm{Al}_{5}$ und MnAl6. Zeitschrift Naturforschung Teil A 1953, 8, 755-776.

46. Chi, J. A Nuclear Magnetic Resonance Probe of Fe-Al and $\mathrm{Al}_{20} \mathrm{~V}_{2} \mathrm{Eu}$ Intermetallics. Ph.D. Thesis, University of Science and Technology of China, Anhui, China, August 2007.

47. Song, Y.K.; Varin, R.A. Indentation microcracking and toughness of newly discovered ternary intermetallic phases in the Ni-Si-Mg system. Intermetallics 1998, 6, 379-393.

48. Shetty, D.K.; Wright, I.G.; Mincer, P.N.; Clauer, A.M. Indentation fracture of WC-Co cermets. J. Mater. Sci. 1985, 20, 1873-1882.

49. Standard Test Method for Knoop and Vickers Hardness of Materials; ASTM E384-11e1; ASTM International: West Conshohocken, PA, USA, 2011.

50. Hausild, P.; Karlik, M.; Siegl, J.; Nedbal, I. Fractographic analysis of the crack growth in the $\mathrm{Fe}_{3} \mathrm{Al}$ based intermetallic alloy. Intermetallics 2005, 13, 217-225.

51. Niu, X.; Wang, L. Effect of transition-metal substitution on electronic and mechanical properties of $\mathrm{Fe}_{3} \mathrm{Al}$ : First-principles calculations. Comput. Mater. Sci. 2012, 53, 128-132.

52. Qiu, R.; Iwamoto, C.; Satonaka, S. Interfacial microstructure and strength of steel/aluminum alloy joints welded by resistance spot welding with cover plate. J. Mater. Process. Technol. 2009, 209, 4186-4193.

53. Wang, J.; Xing, J.; Qiu, Z.; Zhi, X.; Cao, L. Effect of fabrication methods on microstructure and mechanical properties of $\mathrm{Fe}_{3} \mathrm{Al}$-based alloys. J. Alloys Compd. 2009, 488, 117-122.

54. Moradkhani, A.; Baharvandi, H.; Tajdari, M.; Latifi, H.; Martikainen, J. Determination of fracture toughness using the area of micro-crack tracks left in brittle materials by Vickers indentation test. J. Adv. Ceram. 2013, 2, 87-102. 
55. Rocha-Rangel, E.; Refugio-Garcíab, E.; Miranda-Hernández, J.G.; Terrés-Rojas, E. Fracture toughness enhancement for metal-reinforced alumina. J. Ceram. Process. Res. 2009, 10, 744-747.

56. Miao, Y.; Han, D.; Xu, X.; Wu, B. Phase constitution in the interfacial region of laser penetration brazed magnesium-steel joints. Mater. Character. 2014, 93, 87-93.

57. Tang, N.; Li, Y.P.; Kurosu, S.; Koizumi, Y.; Matsumoto, H.; Chiba, A. Interfacial reactions of solid Co and solid Fe with liquid Al. Corros. Sci. 2012, 60, 32-37.

58. Bolelli, G.; Cannillo, V.; Lusvarghi, L.; Rosa, R.; Valarezo, A.; Choi, W.B.; Dey, R.; Weyant, C.; Sampath, S. Functionally graded WC-Co/NiAl HVOF coatings for damage tolerance, wear and corrosion protection. Surf. Coat. Technol. 2012, 206, 2585-2601.

59. Fu, H.; Li, X.; Liu, W.; Ma, Y.; Gao, T.; Hong, X. Electronic and dynamical properties of NiAl studied from first principles. Intermetallics 2011, 19, 1959-1967.

60. Wang, Y.; Wang, Z.; Yang, Y.; Chen, W. The effects of ceria on the mechanical properties and thermal shock resistance of thermal sprayed NiAl intermetallic coatings. Intermetallics 2008, 16, $682-688$.

61. $\mathrm{Wu}, \mathrm{Q}$; $\mathrm{Li}, \mathrm{S}$. Alloying element additions to $\mathrm{Ni}_{3} \mathrm{Al}$ : Site preferences and effects on elastic properties from first-principles calculations. Comput. Mater. Sci. 2012, 53, 436-443.

62. Ozdemir, O.; Zeytin, S.; Bindal, C. Tribological properties of $\mathrm{Ni}_{3} \mathrm{Al}$ produced by pressure-assisted volume combustion synthesis. Tribol. Int. 2012, 53, 22-27.

(C) 2015 by the authors; licensee MDPI, Basel, Switzerland. This article is an open access article distributed under the terms and conditions of the Creative Commons Attribution license (http://creativecommons.org/licenses/by/4.0/). 